\title{
STRATEGI INTERNASIONALISASI DALAM BIDANG PENELITIAN PADA UNIVERSITAS INDONESIA DAN INSTITUT PERTANIAN BOGOR
}

\author{
Esti Suyanti*
}

\begin{abstract}
Higher education in Indonesia is faced with increasing international reputation. Rating issued by various international agencies suggested higher education in Indonesia to conduct various strategic initiatives to bring the institution into a World Class University. University of Indonesia and Bogor Agricultural University as the top universities in Indonesia enacted a series of Organizational Strategy and Program Strategies at various fields, including research toward a process of internationalization of higher education. A series of strategies were then examined using a qualitative research approach through a case study of the document search methods, interview and observation. Results from these studies indicate that the awareness of internationalization, international publications and funding as factors that need to be increased in developing areas of research at the University of Indonesia and Bogor Agricultural University. Based on the data analysis model developed Internationalization Strategy, University of Indonesia and Bogor Agricultural University conducted through six forms of support is the awareness, commitment, planning, operationalization, review and reinforcement in a sustainable manner.
\end{abstract}

Keywords: World Class Research University, Organizational Strategies, program Strategies, Internalization strategy.

\section{PENDAHULUAN}

Pendidikan Tinggi Indonesia dihadapkan pada tantangan menghadapi persaingan global. Gambaran pendidikan tinggi Indonesia pada awal tahun 2000 belum menunjukan adanya daya saing yang tinggi dengan pendidikan tinggi negara lain. Strategi Jangka Panjang Pendidikan Tinggi (HELTS) 2003-2010 menunjukan universitas di Indonesia belum diperhitungkan dalam jajaran universitas top dunia. Selanjutnya dalam HELTS 2003-2010 ditetapkan 3 (tiga) langkah strategi yaitu daya saing, otonomi pendidikan tinggi dan kesehatan organisasi. Sebelum HELTS 2003-2010 dikeluarkan, pemerintah sudah terlebih dahulu memberikan otonomi pendidikan melalui penetapan 4 (empat) Perguruan Tinggi Negeri menjadi Perguruan Tinggi Badan Hukum Negara (PT-BHMN). UI, UGM, ITB dan IPB merupakan 4 (empat) PT-BHMN yang dijadikan pilot project dalam upaya meningkatkan daya saing Perguruan Tinggi Indonesia. Dalam kurun 4 (empat) tahun terakhir Perguruan Tinggi Indonesia dapat menembus rangking 500 perguruan tinggi terbaik dunia, bahkan berdasarkan survey dari Themes Higher Education pada tahun 2009 Perguruan Tinggi Indonesia sudah masuk dalam jajaran 100 dunia Perguruan Tinggi terbaik se-asia.

Tabel 1: Peringkat Perguruan Tinggi Indonesia dalam Skala Dunia

\footnotetext{
* Tenaga Administrasi Pendidikan pada Program Studi Kajian Pengembangan Perkotaan Universitas Indonesia.
} 


\begin{tabular}{|l|c|c|c|c|}
\hline \multirow{2}{*}{ Perguruan Tinggi } & \multicolumn{4}{|c|}{ Peringkat-Tahun } \\
\cline { 2 - 5 } & $\mathbf{2 0 0 9}$ & $\mathbf{2 0 0 8}$ & $\mathbf{2 0 0 7}$ & $\mathbf{2 0 0 6}$ \\
\hline Universitas Indonesia & 201 & 287 & 395 & 250 \\
\hline Universitas Gajah Mada & 250 & 316 & 360 & 270 \\
\hline $\begin{array}{l}\text { Institut Teknologi } \\
\text { Bandung }\end{array}$ & 351 & 315 & 369 & 258 \\
\hline Universitas Airlangga & $401-500$ & $501+$ & 502 & 526 \\
\hline Institut Pertanian Bogor & $501-600$ & $501+$ & 545 & \\
\hline Universitas Diponegoro & $501-600$ & $501+$ & 553 & 495 \\
\hline $\begin{array}{l}\text { Universitas Sebelas } \\
\text { Maret }\end{array}$ & $600+$ & & & \\
\hline
\end{tabular}

Sumber : http://www.topuniversities.com

Perbaikan peringkat beberapa Perguruan Tinggi tersebut tidak terlepas dari peningkatan standar pendidikan dan penelitian yang mengacu kepada aspek-aspek internasional. Seluruh lembaga internasional yang mengeluarkan sistem pemringkatan mensyaratkan dimensi internasional pada fungsi-fungsi yang dilaksanakan oleh Universitas.

Internasionalisasi pada berbagai bidang merupakan strategi yang digunakan oleh Perguruan Tinggi Indonesia untuk menghasilkan pendidikan tinggi berskala dunia atau yang sering dikenal dengan istilah World Class University. Indikator world class university yang dikeluarkan oleh beberapa lembaga internasional memiliki kriteria yang beragam. Salah satunya adalah kriteria penilaian yang dilakukan oleh Themes Higher Education Supplement (THES) yang menekankan pada empat pilar utama yang dinilai pada universitas kelas dunia yaitu : research quality, teaching quality, graduate employability dan international outlook. Universitas Indonesia dan Institut Pertanian Bogor termasuk universitas yang menggunakan konsep universitas berbasis riset untuk mewujudkan institusinya menjadi World Class Research University. Internasionalisasi programprogram unggulan merupakan strategi yang dilakukan oleh Universitas Indonesia dan Institut Pertanian Bogor. Strategi yang ditetapkan oleh Universitas Indonesia dan Institut Pertanian Bogor sesuai dengan karakteristik dan sumberdaya yang dimilikinya. Sehingga universitas memiliki konsep-konsep mengenai strategi internasionalisasi yang bisa saja sama atau berbeda tergantung sudut pandang dan target capainya.

Untuk menjadi World Class Research University diperlukan sebuah proses yang dikenal sebagai internasionalisasi pendidikan. Pandangan-pandangan yang dikemukan oleh berbagai pakar mengenai konsep 'internasionalisasi pendidikan' memiliki beragam pemahaman tergantung pada aspek yang mempengaruhinya. Negara yang berbeda, sistem pendidikan, lembaga dan penyedia pendidikan mungkin memiliki dimensi yang berbeda mengenai 'internasionalisasi pendidikan. Hal ini mungkin saja terjadi karena adanya perbedaan prioritas, budaya dan sejarah, politik dan sumber daya. Konsep internasionalisasi menjadi perhatian pada Pendidikan Tinggi di Indonesia sebagai suatu langkah untuk menuju world class university. Pemerintah sudah mendorong Perguruan Tinggi di Indonesia untuk melakukan proses internasionalisasi salah satunya adalah dengan dipersyaratkan dimensi internasional pada beberpa komponen yang ditentukan dalam borang akreditasi yang dikeluarkan oleh Badan Akreditasi Nasional (BAN) dalam berbagai bidang termasuk riset dan publikasi internasional. Sudut pandang dimensi internasionalisasi yang memiliki makna beragam perlu diukur melalui analisa terhadap strategi-strategi yang ditetapkan oleh institusi. Bertolak dari hal tersebut maka 
studi ini ingin menggambarkan, menguraikan dan menganalisa mengenai strategi internasionalisasi yang dilaksanakan oleh Universitas Indonesia dan Institut Pertanian Bogor khususnya dalam pengembangan penelitian sehingga akan tergambar model internasionalisasi ke dua institusi tersebut. Perbedaan dan persamaan yang akan tergambar dari strategi-strategi yang ditetapkan oleh ke-dua institusi tersebut akan dianalisa secara komparatif untuk mendapatkan deskripsi terhadap permasalahan dan kendala yang dihadapi UI dan IPB dalam menghadapi persaingan antar universitas baik tingkat regional (Asia) dan internasional. World Class University. konsep world class university yang muncul memiliki pemaknaan yang beragam. Altbach dalam Deem, Mook dan Lucas (2010:84) menyatakan: Everyone wants a world-class university. No country feels it can do without one. The problem is that no one knows what a world-class university is, and no one has figured out how to get one. (Setiap orang menginginkan sebuah universitas kelas dunia. Tidak ada negara satupun yang merasa dapat melakukannya. Permasalahannya adalah bahwa tidak ada seorang pun tahu apa itu universitas kelas dunia, dan tidak ada seorang pun tahu cara untuk mendapatkannya).

Salmi (2009:19) mengemukakan pandangan mengenai world class university, pandangan tersebut merupakan konsepsi dari pengabungan pernyataan-penyataan yang dikemukan oleh Altbach 2004; Khoon et al. 2005; Niland 2000. World Class university didefinisikan oleh Salmi sebagai Universitas yang secara teratur mengidentifikasi sejumlah dimensi dasar seperti staf pengajar yang berkualifikasi tinggi; kesempurnaan dalam penelitian, pengajaran berkualitas; sumber pendanaan yang tinggi dari pemerintah dan non pemerintah; mahasiswa internasional dan sangat berbakat; kebebasan akademik; struktur pemerintahan yang otonom dan fasilitas yang lengkap untuk pengajaran, penelitian, administrasi, dan kehidupan siswa. Selanjutnya Salmi (2009:32) mengemukan karakteristik yang dapat mendefinisikan 'universitas kelas dunia' sebagaimana disajikan pada gambar 1 berikut:

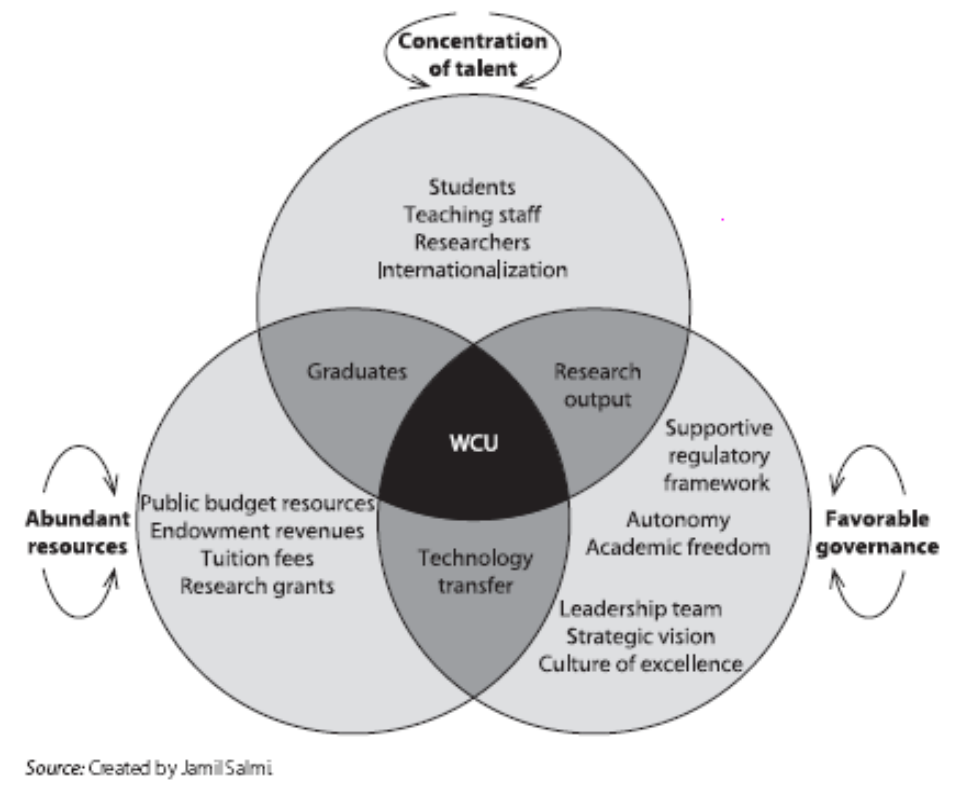

Gambar 1: Characteristics of a World-Class University (WCU): Alignment of Key Factors

Salmi mengemukakan bahwa world class university dapat dicapai dengan memanfaatkan 3 (tiga) faktor kunci yaitu (i) dengan konsentrasi bakat yang tinggi yang dimiliki oleh dosen dan mahasiswa, (ii) sumber daya yang melimpah sehingga dapat menyediakan lingkungan belajar yang nyaman dan tersedianya dana dalam melakukan 
penelitian lanjutan, dan (iii) tata pamong yang baik yang mendorong visi strategis, inovasi dan fleksibilitas serta memungkinkan lembaga untuk membuat keputusan dan mengelola sumber daya tanpa dibebani oleh birokrasi (otonom). Selanjutnya dimensidimensi tersebut saling terintegrasi sehingga tercipta 3(tiga) aspek yang menjadi indikator penilaian sebuah Perguruan Tinggi telah menjadi universitas kelas dunia yaitu (1) lulusan yang memiliki daya serap tinggi di masyarakat; (2) keluaran riset yang berkualitas; (3) transfer teknologi yang memiliki akses tinggi terhadap berbagai informasi. Indikator-indikator tersebut kemudian dipakai oleh lembaga-lembaga internasional dalam melakukan survey guna melakukan perankingan universitas bereputasi dunia. Metode Perankingan yang banyak digunakan sebagai standar penentuan sebuah universitas masuk ke dalam world class university adalah sebagai berikut:

1. The Times Higher Education Supplement (THES), diproduksi oleh Quacquarelli QS Symonds Ltd,

2. Academic Ranking World University (ARWU) yang diselenggarakan Shanghai Jiao Tong University (SJTU).

3. Webometrics, diproduksi oleh Cybermetrics Lab (sebuah unit dari National Research Council, badan penelitian publik utama di Spanyol),

Salah satu aspek penilaian dalam menentukan World Class University adalah penelitian dan publikasi hasil penelitian sebagaimana komponen-komponen penilaian yang ditetapkan oleh THES dan ARWU. Sedangkan versi pemeringkatan lain yaitu webometrik lebih menekan kepada tampilan dan tautan web sehingga tidak pas digunakan dalam penilaian universitas yang mengedepankan riset dalam mewujudkan institusinya sebagai universitas kelas dunia. Penilaian terhadap indikator tersebut disikapi oleh universitas melalui peningkatan penelitian yang berkualitas dan terpublikasi dalam jurnal-jurnal internasional. Upaya yang dilakukan universitas untuk menghasilkan penelitian dan publikasi intenasional dengan mengedepankan dan membangun atmosfer dan kegiatan riset sebagai kekuatan universitas yang terintegrasi dengan pengajaran. Hal tersebut kemudian memunculkan istilah 'world class research university'.

Strategi Internasionalisasi dalam Membangun World Class University. Internasionalisasi pendidikan tinggi didefinisikan sebagai proses integrasi internasional / antar dimensi ke dalam pengajaran, penelitian dan pelayanan dari institusi (Knight, 1997 dalam Scott:2000:99). Masih dalam Scott, Davis dan Olsen mengidentifikasi enam strategi dalam program internasionalisasi: (1) program pelajar internasional, (2) layanan dukungan siswa berskala internasional; (3) penyelenggaraan pendidikan internasional jarak jauh; (4) internasionalisasi pengajar, melalui internasionalisasi dari isi dan bentuk dari kurikulum dan melalui pengalaman internasional; (5) internasional bantuan teknis dan pelatihan; dan (6) internasionalisasi dalam penelitian. Internasionalisasi pendidikan tinggi berimplikasi pada pengejaran image dan kualitas internasional dalam menjadikan intitusi sebagai intitusi yang top dan memiliki kompetisi global (Deem et al. 2008 dalam Yat Wai Lo 2009:735).

Soderqvist (2002:12) memperkenalkan sebuah definisi internasionalisasi pendidikan tinggi yang berfokus pada proses perubahan dan pandangan holistik manajemen di tingkat kelembagaan. Soderqvist mendefinisikan internasionalisasi institusi pendidikan tinggi sebagai sebuah proses perubahan dari sebuah institusi pendidikan tinggi nasional menjadi sebuah lembaga pendidikan tinggi internasional 
terkemuka dengan dimasukkannya dimensi internasional dalam segala aspek dari manajemen holistik untuk meningkatkan kualitas mengajar dan belajar dan untuk mencapai kompetensi yang dikehendaki. Hans De Wit dalam Hans De Wit et all (2005:12) menyimpulkan: Karena dimensi internasional pendidikan tinggi mendapatkan lebih banyak perhatian dan pengakuan, orang cenderung menggunakannya dalam cara yang paling sesuai tujuan mereka. Internasionalisasi Pendidikan Tinggi memiliki prasyarat yang perlu dipenuhi oleh Perguruan Tinggi. Zolfaghari, Sabran dan Zolfaghari, (2010:3) mengemukan bahwa prasyarat internasionalisasi adalah pernyataan visi dan misi, nilai-nilai utama, tujuan yang cerdas dan jasa yang disediakan oleh universitas. Sebelumnya Wang, (2010:3-6) mengemukakan pendapat serupa bahwa untuk membangun World Class University ada beberapa hal yang menjadi perhatian antara lain terkait dengan gagasan. Gagasan universitas menurut Wang menjadi dasar pemahaman civitas akademik terkait dengan semangat, sifat, fungsi dan misi universitas. Gagasan tersebut merupakan filosofi dasar yang menjadi dasar pengembangan universitas baik secara fungsi maupun organisasi. Filosofi tersebut digunakan untuk membangun Universitas Modern yang berkarakter kuat, sehingga konsepsi yang harus dipahami oleh Universitas dalam membangun world class university adalah sebagai berikut:

a) Melakukan internasionalisasi secara benar melalui penetapan-penetapan standar kualitas yang tinggi

b) Terbuka oleh berbagai aspek seperti membuka peluang yang sama bagi sivitas akademik, terbuka terhadap hasil-hasil penelitian kepada masyarakat dan melakukan pelayanan kepada masyarakat.

c) Mengembangkan berbagai disiplin (sosial, sosial sains dan humaniora) dan bidangbidang inter-disiplin

Strategi internasionalisasi yang terbagi menjadi 2(dua) strategi yakni Strategies Programe (Program Strategi) dan Organizational Strategies (Organisasi Strategi) yang tersaji pada tabel 2.

Tabel 2 : Strategi Internasionalisasi

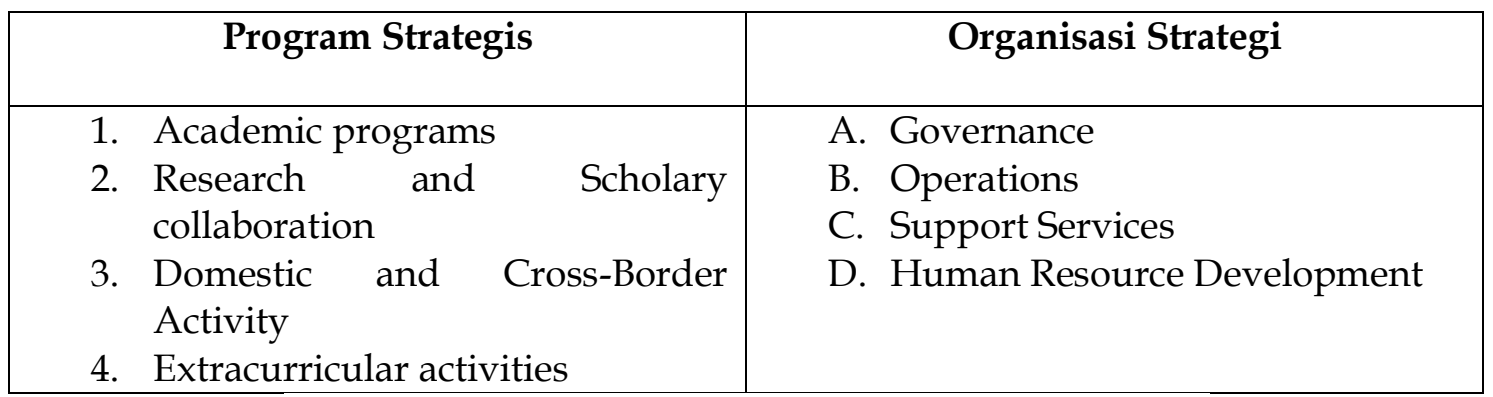

Sumber : Jane Knight (2004) dalam Hans De Wit (2005)

Lebih lanjut Harjanto (2004) dalam Grace at all (2006:18) mengemukakan standar internasional yang diperlukan dalam membangun universitas riset menurut antara lain: (1) mempunyai cukup tenaga pengajar dan peneliti yang bergelar S2 dan S3 (magister dan doktor); (2) mempunyai akses kepada sumber-sumber literatur ilmu pengetahuan seperti internet, jurnal dan perpustakaan; (3) mempunyai kemampuan untuk melaksanakan kontrak atau kerjasama riset (research contract) yang menghasilkan 
paten; (4) mampu menghasilkan doktor atau Ph.D per tahun dan (5) menghasilkan karya ilmiah/paper dengan standar internasional.

Internasionalisasi Program Riset. Internasionalisasi kegiatan penelitian sangat dipengaruhi oleh strategi program dan manajemen yang diterapkan oleh universitas. Knight dalam de Wit (2010:23) membagi pengembangan program riset dalam konteks strategi internasionalisasi sebagai berikut: Area atau Tema Riset Internasional, Kerjasama riset dan Publikasi, Seminar dan Konferensi Internasional, Perjanjian kerjasama riset internasional, Program Pertukaran penelitian, danKerjasama riset dalam bidang akademik pada sektor lainnya. Bushaway (2003:31-32) mengemukakan keberhasilan riset ditentukan oleh manajemen riset yang dilakukan mulai dari tingkat universitas, fakultas/departemen, tim peneliti dan individu peneliti. Manajemen tertinggi yaitu pada tingkat universitas yang berfungsi menetapkan misi, strategy dan dukungan terhadap program riset. Selain itu juga pada tingkat ini berbagai kebijakan dan implemtasinya merupakan tanggung jawab termasuk menjamin ketersediaan dana dan alokasi peneliti.

Model Strategi Internasionalisasi. Knight dalam de Wit (2010:135) mengemukakan frame work model strategi internasionalisasi pendidikan tinggi sebagai berikut:

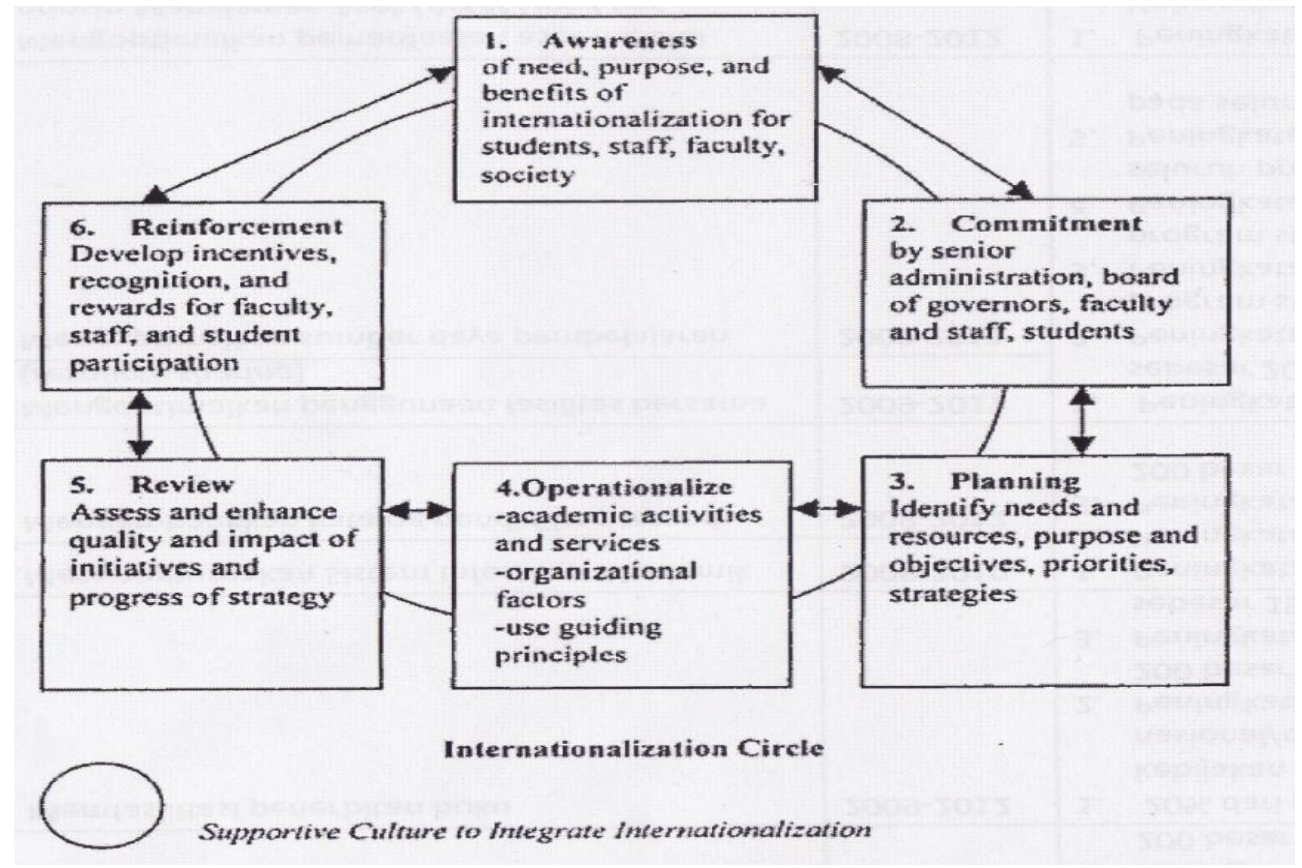

\section{Gambar 2 : Model Strategi Internasionalisasi}

Awareness, menciptakan kesadaran akan pentingnya dan manfaat dari internasionalisasi untuk mahasiswa, staf, dan fakultas. Commitment, $m$ embangun komitmen terhadap proses integrasi dimensi internasional ke dalam pengajaran / pembelajaran, penelitian dan fungsi pelayanan universitas. Planning, mengembangkan rencana komprehensif atau strategi untuk internasionalisasi 
perguruan tinggi. Operational, menerapkan aspek-aspek yang berbeda dari strategi internasionalisasi dan menciptakan budaya yang mendukung kegiatan akademik dan jasa. Review, menilai dan terus meningkatkan kualitas dan dampak dari aspek yang berbeda dari proses internasionalisasi. Reinforcement, penghargaan dan pengakuan fakultas dan partisipasi staf, dengan membangun system insentif dan penghargaan.

Kebijakan Nasional dalam Kerangka Membangun Pendidikan Tinggi Indonesia menjadi World Class University. Konsepsi internasionalisasi pendidikan tinggi tidak terlepas dari pengaruh kebijakan pemerintah dan daya tarik pasar sebagaimana yang dikemukan Qiang, (2010:257) melalui konsep segitiga Clark, yaitu: a: Kekuatan internasional, nasional dan institusi yang saling mempengaruhi dalam membentuk dan menentukan kebijakan nasional untuk pendidikan tinggi. b: Kekuatan antara internasional konteks, pasar dan institusi dalam membentuk kebijakan institusi. c: Kekuatan antara kekuatan internasional, nasional dan pasar dalam membentuk kebijakan nasional untuk pendidikan tinggi. Pemerintah Indonesia menyadari bahwa kekuatan internasionalisasi

sudah menjadi tuntutan yang harus diadaptasi oleh Pendidikan Tinggi Indonesia. Oleh karena itu pada tahun 2003 Pemerintah mengeluarkan Strategi Jangka Panjang Pendidikan Tinggi atau Higher Education Long Term Strategic (HELTS) 2003-2010.

Permasalahan utama pada pendidikan tinggi di Indonesia yang dikemukan dalam HELTS 2003-2010 adalah kurangnya reputasi Perguruan Tinggi Indonesia dibanding Perguruan Tinggi negara lain. Untuk meningkatkan reputasi tersebut terdapat 3 (tiga) strategi yang ditetapkan oleh pemerintah yaitu daya saing bangsa, otonomi dan desentralisasi serta kesehatan organisasi. Proses internasionalisasi Pendidikan Tinggi dapat dilihat dari berbagai sudut pandang, salah satunya adalah pengembangan riset dan hasil-hasilnya berupa publikasi. Warta UI, 2009 memuat informasi bahwa kondisi jumlah publikasi artikel ilmiah di Indonesia dibandingkan dengan negara-negara Asia Tenggara masih relatif tertinggal. Pemerintah Indonesia melalui Kementrian Pendidikan Nasional memiliki beberapa kebijakan yang mendukung pengembangan riset pada universitas di Indonesia. Dukungan tersebut diberikan dalam bentuk grand atau hibah penelitian bersaing yang dapat dimanfaatkan oleh universitas. Keluaran riset yang diwajibkan bagi penerima grand atau hibah tersebut adalah pemuatan karya ilmiah pada jurnal-jurnal internasional. Melalui kebijakan tersebut diharapkan karya ilmiah peneliti Indonesia khususnya yang ada di Perguruan Tinggi dapat terpublikasikan ke jurnal-jurnal internasional.

\section{METODE}

Penelitian ini menggunakan pendekatan kualitatif dengan metode studi kasus. Tempat penelitian dilaksanakan di Universitas Indonesia dan Institut Pertanian Bogor dalam kurun waktu 5 bulan. Yang menjadi informan antara lain: Pejabat Struktural Tingkat Pusat, Pejabat Struktural Tingkat Fakultas/Pusat Penelitian, dan dosen.

\section{HASIL PENELITIAN DAN PEMBAHASAN}

Strategi Internasionalisasi Riset di Universitas Indonesia dan Institut Pertanian
Bogor

\section{Kesadaran Internasionalisasi}


Peningkatan budaya dan iklim penelitian di lingkungan Universitas Indonesia dapat dilihat dari kencenderungan peningkatan jumlah pengusul proposal dan penerima hibah penelitian yang meningkat setiap tahunnya. Pengusul proposal penelitian dari tahun 2008 - 2009 naik lebih dari 300\%. Hal tersebut menunjukan mulai terbentuknya kesadaran dosen/peneliti dalam kegiatan riset. Data artikel yang jurnal internasional yang dihasilkan Universitas Indonesia dalam kurun waktu 2007-2009 secara kuantitas masih relatif minim.

Secara umum penelitian di Institut Pertanian Bogor mengalami peningkatan yang cukup signifikan dalam kurun waktu 2007-2009 yang meningkat dari 351 menjadi 615. Bahkan menurut hasil wawancara yang dilakukan menunjukan bahwa perolehan Paten Institut Pertanian Bogor terbanyak diantara Perguruan Tinggi di Indonesia dengan jumlah capaian sebanyak 149.

Untuk meningkatkan jumlah publikasi internasional, strategi yang dilakukan oleh kedua perguruan tinggi tersebut yaitu mewajibkan para penerima hibah riset untuk menyusun laporan dalam format jurnal internasional dan menyelanggarakan pelatihan dan pendampingan jurnal internasional.

\section{Penguatan Kesadaran Sivitas Akademik Terhadap Proses Internasionalisasi}

Kesadaran dosen/peneliti akan proses internasionalisasi kegiatan riset perlu penguatan-penguatan melalui pemberian apresiasi baik dalam bentuk penghargaan baik dalam bentuk pujian maupun insentif ataupun gelar peneliti berprestasi

\section{Komitmen Senior Administrasi dan Perencanaan}

Bentuk komitmen yang paling nyata adalah pernyataan visi Universitas Indonesia menjadi Universitas Riset Kelas Dunia. Kesinabungan visi setiap periode kepemimpinan merupakan bentuk konsitensi Universitas Indonesia dalam mewujudkan visinya. Komitmen tersebut selanjutnya dituangkan dalam bentuk perencanaan yang sering disebut dengan Rencana Strategis atau Renstra. Sedangkan bentuk komitmen yang ditujukan oleh pimpinan Institut Pertanian Bogor adalah menetapkan visinya menjadi universitas berbasis riset kelas dunia. Renstra Institut Pertanian Bogor 2008-2013 telah menetapkan strategi peningkatan kualitas penelitian dan pengabdian kepada masyarakat meliputi 3 fokus kebijakan, sebagai berikut: Pembinaan Kualitas Penelitian Khususnya Penelitian Terobosan Bertaraf Internasional, Pengelolaan dan Pemanfaatan Hasil Penelitian, dan Pengembangan Kelembagaan Penelitian yang Terarah

\section{Penerapan}

DRPM Universitas Indonesia sebagai direktorat yang bertanggung jawab dalam pengembangan riset di Universitas Indonesia menetapakan serangkaian program-program kegiatan dalam bentuk program kerja yang dikoordinasi oleh beberapa sub-bidang yang ada. DRPM bertanggung jawab terhadap pelaksanaan hibah riset dan keluaran berupa publikasi internasional yang didukung oleh program-program pelatihan untuk peningkatan kemampuan menulis bagi dosen dan peneliti. Selain itu program-program lain yang sedang dan terus berlangsung seperti peningkatan kegiatan seminar dan konferensi internasional; peningkatan jurnal dari taraf nasional menjadi internasional dengan memberikan pelatihan 
bagi pengelolaanya dan mengadakan pendampingan; peningkatan implementasi kerjasama riset internasional.

Pada dokumen world class university Institut Pertanian Bogor termuat program-program yang dilaksanakan untuk meningkatkan reputasi Institut Pertanian Bogor di dunia yaitu : Building awareness publikasi internasional dilakukan dengan kegiatan pelatihan yang yang dirancang dan diperuntukkan bagi tenaga pendidik bergelar Master/Doktor yang baru menyelesaikan studi di dalam dan luar negeri (new returnee), punya pengalaman menulis disertasi (publikasi ilmiah) dan bagi para peneliti penerima hibah-hibah penelitian. Fasilitas Proses Internasionalisasi Karya Ilmiah; Program ini ditujukan untuk penguatan terhadap jurnal yang ada

dilingkungan IPB. Mengembangkan Jejaring Internasional yang Efektif IPB sebagai perguruan tinggi pertanian terkemuka, menempatkan WCU (World Class University) sebagai arah pengembangan dan target positioning IPB di masa yang akan datang.

\section{Monitoring dan Evaluasi}

Monitoring dan evaluasi (monev) kegiatan penelitian di Universitas Indonesia dilakukan sejak awal peneliti mengajukan usulan penelitian yang akan dikerjakan sampai dengan pelaporan hasil akhir penelitian. Paling sedikit 3(tiga) kali peneliti mempersentasikan penelitiannya dihadapan riviewer sesuai dengan bidang ilmunya. Adapun proses monitoring di Institut Pertanian Bogor dilakukan dalam sebuah sistem gugus mutu, yaitu mengundang para peneliti dalam bidangnya kemudian disampaikan pelaksanaan kegiatan penelitian dan peneliti siapa saja yang terlibat di dalamnya. Selain itu Institut Pertanian Bogor mewajibkan penelitinya untuk mempublikasi hasil penelitian ke dalam jurnal internasional karena publikasi pada jurnal yang berwasit seperti SCOPUS dan terdaftar dalam indeks sitasi menjadi parameter penilaian yang sangat menentukan dalam penentuan universitas sebagai universitas kelas dunia.

\section{PENUTUP}

Kesimpulan. 1) Pimpinan universitas sudah meletakan landasan bagi pengembangan riset yang berorientasi pada pencapaian internasional hal tersebut tergambar dalam visi menuju universitas kelas dunia (world class university). Dukungan institusi terhadap program internasionalisasi riset, dilakukan dengan membentuk unit-unit yang bertanggung jawab terhadap kegiatan riset termasuk strategi dan program internasionalisasi riset. Selain itu pendanaan yang memadai juga menjadi perhatian institusi untuk meningkatkan jumlah penelitian. 2) Secara umum UI dan Institut Pertanian Bogor memiliki SDM yang memadai baik dari segi kuantitas maupun kualitas. Peningkatan jumlah riset setiap tahunnya menunjukan bahwa iklim dan budaya penelitian dosen/peneliti sudah terbangun. 3) Program-program riset yang mengarah ke dimensi internasionalisasi sudah terselenggara dilihat dari aktivitas-aktivitas yang ada. Perhatian dosen terhadap publikasi hasil penelitian masih kurang, dilihat dari jumlah publikasi pada jurnal internasional yang memiliki sitasi dan indeks faktor yang tinggi. 
Saran. Penelitian ini masih terbatas pada pandangan-pandangan manajemen universitas terhadap proses dan strategi internasionalisasi yang dilaksanakan di Universitas Indonesia dan Institut Pertanian Bogor dan hanya difokuskan pada bidang penelitian. Kiranya penelitian serupa dapat dilaksanakan dengan melihat persfektif dari para peneliti/dosen atau bidang lainnya yang berpengaruh terhadap internasionaliasi pendidikan tinggi seperti program pengembangan akademik. 


\section{DAFTAR RUJUKAN}

Bushway, Robert. W, Managing Research. GBR: McGraw Hill, 2003.

De Wit, Hans. Internalization of Higher education in The United State of America and Europe : A Historical, Comparative and Conceptual Analysis. London: Briitish Library .2010 (www.google.co.id)

De Wit, Hans; Jaramillo, Isabel Critina; Knight, Jane (ed). Higher Education in Latin America: The International Dimension. Washington DC: World Bank, 2005

Deem, Rosamary; Mok, Ka Ho; Lucas, Lisa, Transformning Higher Education in Whose Image?: Exploring the Concept of the 'World-Class' University in Europe and Asia. 2010 (www.international.ac.uk/resouches/trans.pdf)

Faulkner, David O dan Campbell, Andrew. The Oxford Handbook of Strategy. New York: Oxford. 2003

Grace, Nani et all. Kajian Knowledge Management pada Perguruan Tinggi Menuju Kesiapan Universitas Riset. Jakarta:LIPI. 2006

Qiang, Zang. Internationalization of Higher Education: Toward Conseptual Framework . 2010. (www.unal.edu.co/ori/red-orion/docs/Conceptual-FrameworkInternalization.pdf)

Salmi, Jamil, Challenge of Establishing World Class Universities. Washington DC: World Bank, 2009

Scott, Peter (ed). Higher Education Reformed. London and New York: Falmer Press. 2000

Wang, Yingjie. Building the World Class University in Developing Country: Universal, Uniqueness, and Cooperation. 2010 (www.springlink.com.index/UX83466748520778.pdf)

Yat Wai Lo, William, Reflections on internationalisation of higher education in Taiwan: perspectives and prospects , 2010 (www.Springerlink.com/index/1808106u3411mp.pdf)

Zolfaghari, Akbar; Sabran, M.S; Zolfaghari Ali. Internationalization of higher education: Challenges, strategies, policies and programs. 2010. (www.teacher.org.cn/doc) 